$$
\begin{aligned}
& \text { ANALT/CP-81839 } \\
& \text { Conf-940440--2 }
\end{aligned}
$$

\title{
EFFECT OF NIOBIUM INTERLAYER ON HIGH-TEMPERATURE SLIDING FRICTION AND WEAR OF SILVER FILMS ON ALUMINA
}

\author{
A. Erdemir and R. A. Erck \\ Energy Technology Division \\ Argonne National Laboratory \\ Argonne, IL 60439
}

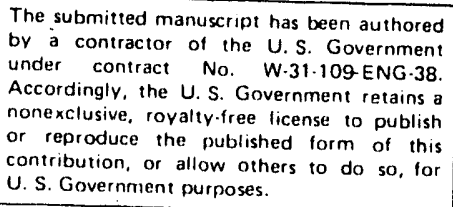

To be presented at the International Conference on Metallurgical Coatings and Thin Films, ICMCTF-94, San Diego, CA April 25-29, 1994

*Work supported by the Tribology Program, Office of Transportation Materials, U.S. Department of Energy, under Contract W-31-109-Eng-38.

\section{DISCLAIMER}

This report was prepared as an account of work sponsored by an agency of the United States Government. Neither the United States Government nor any agency thereof, nor any of their employees, makes any warranty, express or implied, or assumes any legal liability or responsibility for the accuracy, completeness, or usefulness of any information, apparatus, product, or process disclosed, or represents that its use would not infringe privately owned rights. Reference herein to any specific commercial product, process, or service by trade name, trademark, manufacturer, or otherwise does not necessarily constitute or imply its endorsement, recommendation, or favoring by the United States Government or any agency thereof. The views and opinions of authors expressed herein do not necessarily state or reflect those of the United States Government or any agency thereof.

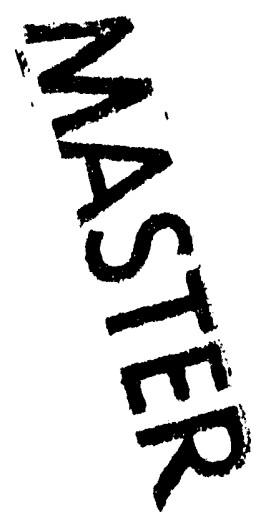




\title{
EFFECT OF NIOBIUM INTERLAYER ON HIGH-TEMPERATURE SLIDING FRICTION AND WEAR OF SILVER FILMS ON ALUMINA
}

\author{
A. Erdemir and R. A. Erck \\ Energy Technology Division \\ Argonne National Laboratory \\ Argonne, IL 60439
}

\begin{abstract}
We investigated the effect of a thin $\mathrm{Nb}$ bond layer (15-20 nm thick) on the high-temperature sliding friction and wear of silver films $\left(\approx 1.5 \mu \mathrm{m}\right.$ thick) produced on $\alpha$-alumina $\left(\mathrm{Al}_{2} \mathrm{O}_{3}\right)$ substrates by ion-beam assisted deposition. The friction coefficients of test pairs without an $\mathrm{Ag}$ film fluctuated between 0.8 to 1.1, whereas the friction coefficients of pairs with an $\mathrm{Ag}$ film were 0.32 to 0.5 . The wear of uncoated $\mathrm{Al}_{2} \mathrm{O}_{3}$ balls sliding against the Ag-coated flats was reduced by factors of 25 to $\approx 2000$, depending on test temperature and the presence or absence of an $\mathrm{Nb}$ bond layer. The wear of silver-coated flats was virtually unmeasurable after tests at temperatures up to $400^{\circ} \mathrm{C}$. At much higher temperatures (e.g., $\left.600^{\circ} \mathrm{C}\right), \mathrm{Ag}$ films without an $\mathrm{Nb}$ bond layer delaminated from the sliding surfaces and lost their effectiveness; however, $\mathrm{Ag}$ films with an $\mathrm{Nb}$ bond layer remained intact on the sliding surfaces of the $\mathrm{Al}_{2} \mathrm{O}_{3}$ substrates even at $600^{\circ} \mathrm{C}$ and continued to impart low friction and low wear.
\end{abstract}




\section{INTRODUCTION}

Because of their unique mechanical and chemical properties, advanced structural ceramics and composite materials have attracted a great deal of attention from engine manufacturers in recent years [1-6]. However, the recent studies have demonstrated that, without proper lubrication, both the friction coefficients and the wear rates of most ceramics are unacceptably high. Specifically, unlubricated friction and wear performance of most ceramics was shown to be rather poor during sliding against themselves or other engineering materials, especially at elevated temperatures [2,3,7-11]. It is now believed that without the development of appropriate lubricants, the widespread utilization of most structural ceramics in engines and other tribological applications is highly unlikely [9-12].

In a number of investigations, the feasibility of the lubrication of ceramics with vapor, liquid, and solid lubricants has been explored in past years [13-20]. It was found that at elevated temperatures, most liquids tend to break down or undergo oxidation, thus losing their effectiveness [13,14]. Also, most additives used in these lubricants were incompatible with ceramic surfaces in that the boundary films needed under severe contact conditions were missing and the friction coefficients were high.

In another study, vapor-phase lubrication was shown to be quite effective in controlling friction and wear of ceramics [15]. Thin carbonaceous films resulting from a catalytic reaction between carbon-bearing gases and hot ceramic surfaces were also shown to afford low friction and wear to sliding ceramic surfaces especially at elevated-temperatures [16].

As for the lubrication of ceramics with thin solid films, it was demonstrated that with the use of ion-beam-mixing [17,18] and ion-beam-assisted deposition (IBAD) [19-21], very adherent films of various solid lubricants could be deposited on ceramic substrates and very low friction coefficients and wear rates are obtained $[22,23]$. 
Among others, thin silver films were shown to be very effective in lowering friction and wear of sliding $\mathrm{Al}_{2} \mathrm{O}_{3}, \mathrm{ZrO}_{2}$, and $\mathrm{Si}_{3} \mathrm{~N}_{4}$ surfaces [19,20,22]. These films, prepared in an IBAD system under Ar ion bombardment, possessed excellent adhesion at room temperature. Sputter cleaning of ceramic substrates with either oxygen ions or a combination of argon and oxygen ions were later found to promote even stronger adhesion, hence better tribological performance $[21,22]$. These adherent silver films could function at temperatures up to $400^{\circ} \mathrm{C}$ [24]. At much higher temperatures, they tended to delaminate from ceramic substrates and form discrete islands of silver.

Recently, predeposition of a reactive metal, such as $\mathrm{Ti}, \mathrm{Cr}$, and $\mathrm{Nb}$, was shown to promote even greater adhesion between $\mathrm{Ag}$ films and ceramic substrates. It is conceivable that such a reactive metal interlayer can maintain good film-to-substrate adhesion at high-temperatures as well, hence can provide low friction and wear. Therefore, in this paper we present the effects of a $\mathrm{Nb}$ bond layer (15-20 $\mathrm{nm}$ thick) on friction and wear characteristics of IBAD-silver films on $\alpha$-alumina $\left(\mathrm{Al}_{2} \mathrm{O}_{3}\right)$ substrates at temperatures to $600^{\circ} \mathrm{C}$. For comparison, the results of the earlier tests on IBAD-Ag films without a bond layer [24] were also included.

\section{EXPERIMENTAL DETAILS}

\section{Material}

Flat $\mathrm{Al}_{2} \mathrm{O}_{3}$ specimens, with nominal dimensions of $38.1 \times 50.8 \times 4.2 \mathrm{~mm}$, average surface roughness of about $0.3 \mu \mathrm{m}$ center-line-average (CLA), and grain sizes of 10 to $20 \mu \mathrm{m}$ were obtained from a commercial company. According to the technical specifications provided by this company [25], the $\mathrm{Al}_{2} \mathrm{O}_{3}$ specimens were fabricated from high-purity $\alpha-\mathrm{Al}_{2} \mathrm{O}_{3}$ powders by sintering in air at $\approx 1800^{\circ} \mathrm{C}$. 12.7 -mm-diameter $\mathrm{Al}_{2} \mathrm{O}_{3}$ balls with a surface finish of better than $0.01 \mu \mathrm{m}$ CLA were used as counterparts in the wear-test machine. The volume porosity of the test materials was less than $1 \%$ and the bulk Vickers hardness was about 16 GPa. Before the 
wear testing and/or film deposition, the specimens were ultrasonically cleaned by a method described in Ref. 26.

\section{Ion-Beam-Assisted Deposition of $\mathrm{Ag}$}

Silver was chosen as the film material mainly because of its excellent thermal and chemical stabilities over wide temperature ranges and its low shear strength. In addition, its very high thermal conductivity can help rapidly dissipate frictional heat generating during sliding, hence reduce the thermal and/or thermomechanical wear of ceramic surfaces $[22,23]$. In the past, silver has been used to lubricate $x$-ray vacuum tube bearings and various components in aerospace mechanisms, and has served as an important ingredient of the PS-200 (a plasmasprayed self-lubricating coating) [27] and the PM-200 (a powder metallurgical version of PS200) [28] series of self-lubricating composite materials developed by NASA scientists.

Thin silver films were produced on the $\mathrm{Al}_{2} \mathrm{O}_{3}$ substrates in an ion-beam-assisted-deposition system with and without a $15-20 \mathrm{~nm}$-thick $\mathrm{Nb}$ bond layer. The $\mathrm{Ag}$ films without an $\mathrm{Nb}$ bond layer were deposited under $\mathrm{Ar}+\mathrm{O}$ ion-bombardment. Prior to deposition of $\mathrm{Ag}$, the substrates were sputter-cleaned with the $\mathrm{Ar}+\mathrm{O}$ ion flux. As reported earlier, this type of deposition sequence can impart strong adhesion (room temperature) between $\mathrm{Ag}$ films and $\mathrm{Al}_{2} \mathrm{O}_{3}$ substrates [21].

The Ag films with an $\mathrm{Nb}$ bond layer was deposited under the same conditions but without the use of $O$ ions. Typical base pressures in the turbopumped IBAD system were $\approx 10^{-5}$ Pa before deposition and $\approx 10^{-2} \mathrm{~Pa}$ during deposition. The evaporation rate was measured and controlled by a quartz-crystal rate monitor during the IBAD of Ag. Film thickness in our study was in the range of 1.5 to $1.8 \mu \mathrm{m}$. Figure 1 depicts a schematic illustration of the IBAD system used in this study. Further details of this system and the structural and adhesion characteristics of typical IBAD films can be found in Refs. 19, 22, 24 and 29. 
Friction and Wear Tests

Friction and wear tests were performed with pairs of $\mathrm{Al}_{2} \mathrm{O}_{3}$ balls and $\mathrm{Al}_{2} \mathrm{O}_{3}$ flats, and $\mathrm{Al}_{2} \mathrm{O}_{3}$ balls and IBAD-Ag-coated $\mathrm{Al}_{2} \mathrm{O}_{3}$ flats in an oscillating ball-on-flat-type wear test machine. Typically, the ball specimens were drawn back and forth across the stationary flats at a frequency of $1 \mathrm{~Hz}$ and for a stroke length of $25 \mathrm{~mm}$. This results in an average sliding velocity of $0.05 \mathrm{~m} / \mathrm{s}$. The number of sliding cycles was 4000 ( 8000 passes).

The 12.7-mm diameter $\mathrm{Al}_{2} \mathrm{O}_{3}$ balls were firmly secured to an oscillating holder of the ball-onflat test rig shown in Fig. 2. The dead weight on top of the oscillating ball was maintained at $5 \mathrm{~N}$ which created an initial mean Hertzian contact pressure of about $0.63 \mathrm{GPa}$ on the uncoated flats.

Test temperatures of $200^{\circ} \mathrm{C}, 400^{\circ} \mathrm{C}$, and $600^{\circ} \mathrm{C}$, were maintained by electrical cartridge heaters inserted in the upper and lower stainless-steel enclosures that housed the ball-and-flat specimens. Further details of this tester are given in Ref. 20. All tests were performed under unlubricated sliding conditions in open air of $20 \pm 4 \%$ relative humidity. Frictional force was monitored with a strain-gauge transducer. The measurement of wear volume for the balls was based on the microscopic determination of the wear-scar diameter, which was subsequently converted into wear volume. The wear rate was expressed in terms of the wear volume $\left(\mathrm{mm}^{3}\right)$ of balls divided by contact load $(\mathrm{N})$ and total sliding distance $(\mathrm{m})$ (i.e., $\mathrm{mm}^{3} / \mathrm{N}$.m). The wear of flats was assessed with the aid of a surface profilometer. Duplicate tests were run at each temperature, and the average values of friction coefficients and wear rates are reported.

\section{RESULTS}

Figure 3 shows the average wear rates of the uncoated balls slid against the uncoated and Agcoated flats with and without the $\mathrm{Nb}$ bond layer. Values in the bottom table show the actual 
wear rates in $10^{-7} \mathrm{~mm}^{3} / \mathrm{N} . \mathrm{m}$. In general, the average wear rates of the balls sliding against uncoated flats increase with increasing temperature. Scanning-electron microscopy of the sliding surfaces of uncoated balls and flats revealed that the dominant cause of wear was microfracture. At elevated temperatures, some features suggesting plastic flow were also seen on the rubbing surfaces of uncoated balls and flats, but at higher magnifications, it became clear that these features were mainly due to compacted and/or smeared wear-debris particles with sizes ranging from 10 to $100 \mathrm{~nm}$. In general, regardless of the test temperature, the dominant wear mechanism was microfracture.

As evident from Fig. 3, the wear rates of the $\mathrm{Al}_{2} \mathrm{O}_{3}$ balls sliding against the IBAD-Ag-coated $\mathrm{Al}_{2} \mathrm{O}_{3}$ flats are markedly lower than those of the balls slid against uncoated flats. Based on values provided in the bottom entries, the wear rates of balls are reduced by factors of 25 to $\approx 2000$, depending on test temperature and the presence or absence of an $\mathrm{Nb}$ bond layer. In general, the films with an $\mathrm{Nb}$ bond layer provided better protection against wear than those without an $\mathrm{Nb}$ layer, especially at high temperatures. The wear rates of the IBAD-Nb-Agcoated $\mathrm{Al}_{2} \mathrm{O}_{3}$ flats were too low to be assessed by a surface profilometer even after tests at $600^{\circ} \mathrm{C}$. A 3-dimensional surface map in Fig. 4a reveals that an uncoated $\mathrm{Al}_{2} \mathrm{O}_{3}$ flat had suffered severe wear losses, whereas an IBAD-Nb-Ag-coated $\mathrm{Al}_{2} \mathrm{O}_{3}$ flat had experienced very little wear even after tests at $600^{\circ} \mathrm{C}$ (see Fig. 4b). As is evident from the SEM micrographs in Figs. 5a and $5 b$, only the tips of underlying asperities were exposed and slightly worn away (appearing as dark spots in SEM image). The apparent wear track in Fig. 4b may have been due the plastic flow of silver film, since the depth of wear track is comparable to the original thickness of silver film.

Without the $\mathrm{Nb}$ bond layer, $\mathrm{Ag}$ films could provide lubrication to sliding surfaces up to $400^{\circ} \mathrm{C}$. When tested at $600^{\circ} \mathrm{C}$, they delaminated and lost their effectiveness. As is clear from Fig. 3, the wear of balls sliding against these Ag-coated flats increased dramatically during tests at $600^{\circ} \mathrm{C}$. However, $\mathrm{Ag}$ films with an initial $\mathrm{Nb}$ bond layer remained intact on the sliding 
surfaces of the $\mathrm{Al}_{2} \mathrm{O}_{3}$ substrates even during tests at $600^{\circ} \mathrm{C}$ and continue to provide low friction and wear. Fig. 6 shows the physical condition of the Ag films with and without an $\mathrm{Nb}$ bond layer after exposure to $600^{\circ} \mathrm{C}$. As is evident, the films without an $\mathrm{Nb}$ bond layer largely delaminated and coalesced to form discrete island, whereas, the films with an $\mathrm{Nb}$ bond layer remained intact on the surface, but underwent some grain growth.

The steady-state friction coefficients of test pairs are presented in Fig. 7. The friction coefficients of $\mathrm{Al}_{2} \mathrm{O}_{3}$ balls sliding against $\mathrm{Al}_{2} \mathrm{O}_{3}$ flats are quite high at room temperature, i.e., 0.8 , and tend to go even higher with increasing temperature, i.e., 1.1 at 400 and $600^{\circ} \mathrm{C}$. However, the friction coefficients of balls sliding against the IBAD-Ag-coated flats are substantially low, e.g., $0.35-0.5$ during tests to $400^{\circ} \mathrm{C}$. At $600^{\circ} \mathrm{C}$, their friction coefficients increase substantially and become comparable to those of pairs without the Ag film.

The friction coefficient of $\mathrm{Al}_{2} \mathrm{O}_{3}$ balls sliding against the IBAD-Nb-Ag-coated flats remain low, e.g., 0.4, even during tests at $600^{\circ} \mathrm{C}$. Microscopic inspection of the wear tracks revealed that those $\mathrm{Ag}$ films without an $\mathrm{Nb}$ bond layer were effectively removed from the rubbing surfaces of $\mathrm{Al}_{2} \mathrm{O}_{3}$ flats. However, with an $\mathrm{Nb}$ bond layer, the $\mathrm{Ag}$ films were still intact and providing good coverage. After most sliding tests, we visually noticed that some silver had transferred to and around the wear scars of $\mathrm{Al}_{2} \mathrm{O}_{3}$ balls.

\section{DISCUSSION}

The results presented above demonstrate that with the use of adherent-Ag coatings, both the friction coefficients and the wear rates of sliding $\mathrm{Al}_{2} \mathrm{O}_{3}$ pairs can be lowered markedly (see Figs. 3 and 7). It is important to remember that a solid lubricant film must meet three important criteria in order to be effective on sliding surfaces. First of all, it must adhere strongly to its substrate, otherwise it can be easily removed from the sliding surfaces under the influence of frictional traction. Secondly, the solid lubricant film must be thick enough to 
prevent opposing asperities from coming into frequent contacts, otherwise both friction and wear can be high. Finally, the film must provide easy shear to sliding interface so that the tangential forces are subdued and the friction coefficient is lowered. The friction and wear data presented in Figs. 3 and 7 demonstrate that the $\mathrm{Ag}$ films produced in this study satisfied these conditions quite well.

For the high wear rates of uncoated flats and balls (see Fig. 3), we propose the following interpretation. First of all, we believe that these high wear rates were largely due to the inherently brittle nature of the $\mathrm{Al}_{2} \mathrm{O}_{3}$ material. Secondly, larger tensile forces that develop behind the moving surface asperities (when friction coefficients are high) were also responsible for greater microfracture and thus higher wear rates. As elaborated by Hamilton and Goodman in Ref. 30 and Hamilton in 31, when two solid bodies are brought into contact and forced to slide over one another, the magnitude and the location of subsurface stress fields around the contact zone are determined by the extent of friction coefficient. They analytically showed that when the friction coefficient exceeds $\approx 0.3$, the magnitude of the shear forces between sliding pairs is substantially increased and the location of maximum shear contour is shifted from the subsurface to the sliding surface. As a general rule, the higher the friction coefficient, the higher the magnitude of shear force on a sliding surface and its tensile component developing behind the moving surface asperities.

It the present study, we found that the steady-state friction coefficients of pairs without $\mathrm{Ag}$ films were about 0.8 at room temperature and increased to 1.1 during tests at 400 and $600^{\circ} \mathrm{C}$. Consequently, it is reasonable to conclude that the higher wear rates of balls at elevated temperatures (see Fig. 3) were largely due to the fact that the magnitude of the tensile forces that develop behind the moving surface asperities were noticeably higher.

Because of its poor fracture toughness, polycrstalline form of $\mathrm{Al}_{2} \mathrm{O}_{3}$ cannot sustain large strain energy before undergoing brittle fracture, especially when subjected to a large tensile force. 
Also, as reported in Refs. 20 and 32, the hardness of $\mathrm{Al}_{2} \mathrm{O}_{3}$ ceramics decreases substantially with increasing temperature. The exact role of decreasing hardness in increasing wear rates is not yet well-understood. However, it is conceivable that initiation of microcracks from internal volume defects (e.g., porosities, flaws) may become easier. These volume defects can act as stress concentrators and reduce the fracture strength of $\mathrm{Al}_{2} \mathrm{O}_{3}$, especially at high temperatures [33]. Furthermore, interg-anular debonding due to weakening of grain boundaries and/or grainboundary phases may have been augmented, thus facilitating grain pullouts and/or separation [33]. Microscopic inspection of sliding surfaces of balls and flats supported this interpretation by revealing extensive microcracks (both inter- and intragranular types).

As for the sliding pairs with an Ag-film, we believe that, mainly because of reduced friction the detrimental effects of surface tensile forces generating behind sliding asperities were significantly reduced. As a result, the probability of microcrack initiation on sliding surfaces was insignificant [30]. Furthermore, because of the larger load-bearing area afforded by the easily shearing Ag films (see Fig. 5) the contact load was spread over a much larger area and the magnitude of normal stresses acting on contact spots was reduced. As is evident from Fig. 7, the friction coefficients of pairs with silver films tend to decrease as test temperature increases. This can be attributed to the thermal softening of $\mathrm{Ag}$, making it shear more easily and thus provide lower friction coefficients.

Despite concentrated contacts, high-ambient temperatures, and several thousands of sliding cycles, most $\mathrm{Ag}$ films produced in this study remained intact on sliding surfaces. Highmagnification microscopic inspection of these wear tracks revealed that only the tips of original surface asperities were exposed and slightly worn away (see Fig. 5). We believe that strong film-to-substrate adhesion provided by the IBAD process and $\mathrm{Nb}$ bond layer played a major role in the long endurance lives of the Ag films. 
The study of metal-ceramic interfaces poses many thereoretical and experimental difficulties [35-37]. Bulk thermodynamic calculations are not directly applicable to bonding at the interface because the interfaces is two dimensional and the compositions of interfacial phases (if any exist) are generally not known. In previous studies, we verified that without strong adhesion, $\mathrm{Ag}$ films could easily be removed from the sliding surfaces of $\mathrm{Al}_{2} \mathrm{O}_{3}$ substrates during wear tests [19-23]. As demonstrated in these studies, sputter cleaning of substrate surfaces with an ion flux consisting of $\mathrm{Ar}+\mathrm{O}$ or $\mathrm{O}$ only can markedly improve adhesion between $\mathrm{Ag}$ films and ceramic sibstrates [21,34]. Furthermore, predeposition of a reactive metal bond layer, such as $\mathrm{Ti}, \mathrm{Nb}$ or $\mathrm{Cr}$, was found to provide even stronger adhesion between $\mathrm{Ag}$ films and ceramic substrates [35]. Using a pull-type adhesion test machine, these Ag films could not be detached from their substrates. Detachment always occurred between the adhesive glue and the film itself. Adhesive glue had a tensile strength of about $70 \mathrm{MPa}$, which means that the adhesive strength of these Ag films was $>70 \mathrm{MPa}[35]$.

The precise role of $\mathrm{Nb}$ bond layers in improved film adhesion is not yet known. However, we believe that when such a highly reactive metal is deposited first on the atomically clean surface of $\mathrm{Al}_{2} \mathrm{O}_{3}$ substrate, greater chemical bonding is achieved at the ceramic interface and strong metallic bonding at $\mathrm{Nb} / \mathrm{Ag}$ interface. The results reported here show that an $\mathrm{Nb}$ bond layer substantially increases adhesion, and that good adhesion persists to $600^{\circ} \mathrm{C}$. This finding is consistent with experimental adhesion results for metals on $\mathrm{Al}_{2} \mathrm{O}_{3}$. Some information about $\mathrm{Nb}$ $\mathrm{Al}_{2} \mathrm{O}_{3}$ exists [38] but no direct comparison of adhesion of $\mathrm{Ag}$ and $\mathrm{Nb}$ to $\mathrm{Al}_{2} \mathrm{O}_{3}$ seems to be available. However, many results show that the adhesion of metals to oxide substrates is a function of the standard free energy of formation $\left(\Delta \mathrm{G}_{\mathrm{f}}\right)$ of the corresponding metal oxide. For metals on $\mathrm{Al}_{2} \mathrm{O}_{3}$ a dependence of adhesion on $\mathrm{OG}_{\mathrm{f}}$ was noticed, adhesion being measured by the scratch test [39]. Ag and Au possessed the lowest adhesion whereas metals such as $\mathrm{Ti}$ and $\mathrm{Cr}$ possessed the highest, and $\mathrm{Cu}$ and $\mathrm{Cd}$ were intermediate. This was consistent with the ranking $o \mathrm{LG}_{\mathrm{f}}$ for metal-oxide formation. The work of adhesion, measured using wetting-angle measurements, varied linearly with $\Delta \mathrm{G}_{\mathrm{f}}[40]$. The magnitude of $\Delta \mathrm{G}_{\mathrm{f}}$ for $\mathrm{NbO}$ is somewhat less 
than $\mathrm{TiO}$, but considerably greater than $\mathrm{CdO}$ or $\mathrm{CuO}[41]$. In contrast, $\Delta \mathrm{G}_{\mathrm{f}}$ for $\mathrm{AgO}$ is very small. Thus, bonding between $\mathrm{Nb}$ and $\mathrm{Al}_{2} \mathrm{O}_{3}$ should be excellent. If this relationship is valid at higher temperatures, it helps explain the poor performance of $\mathrm{Ag}$ at $600^{\circ} \mathrm{C} . \mathrm{Ag}_{2} \mathrm{O}$ decomposes above $\approx 230^{\circ} \mathrm{C}$, but $\mathrm{NbO}$ is still stable. and the bonding layer continues to provide good adhesion.

\section{CONCLUSIONS}

1. Adherent $\mathrm{Ag}$ films produced in this study can dramatically reduce the wear of $\mathrm{Al}_{2} \mathrm{O}_{3}$ balls and flats. Specifically, the wear rates of balls are reduced by factors of 25 to $\approx 2000$, depending on test temperature and the presence or absence of an $\mathrm{Nb}$ bond layer while the wear of flats were reduced to unmeasurable levels.

2. Dry sliding of uncoated $\mathrm{Al}_{2} \mathrm{O}_{3}$ balls against uncoated flats results in severe wear damage and high frictional losses. Increased temperatures are detrimental to the friction and wear behavior of $\mathrm{Al}_{2} \mathrm{O}_{3}$. Microfracture is the dominant cause of wear.

3. Ag films without an $\mathrm{Nb}$ bond layer remained intact on sliding $\mathrm{Al}_{2} \mathrm{O}_{3}$ surfaces at temperatures up to $400^{\circ} \mathrm{C}$, but delaminated at $600^{\circ} \mathrm{C}$ and lost its effectiveness, whereas $\mathrm{Ag}$ films with an initial $\mathrm{Nb}$ bond layer remained intact and provided low friction and wear to the sliding $\mathrm{Al}_{2} \mathrm{O}_{3}$ surfaces at temperatures to $600^{\circ} \mathrm{C}$.

\section{ACKNOWLEDGMENT}

This work was supported by the Tribology Program, Office of Transportation Materials, U.S. Department of Energy, under Contract W-31-109-Eng-38. 


\section{REFERENCES}

1. H. Kawamura, "Development Status of Isuzu Ceramic Engine", SAE SP-738, Paper No: 880011, 1998.

2. Tribology of Ceramics, NMAB Publication \# 435, National Materials Advisory Board, National Academy Press, (1988).

3. K. F. Dufrane, Ceram. Eng. Sci. Proc, 9(1988)1409.

4. D. C. Kranmer, STLE Trans., 31(1988)164.

5. R. Kamo and W. Bryzik, Automotive Eng., 87(1979) 59.

6. S. Timoney and G. Flynn, SAE Paper No: 830313, 1983.

7.D. C. Cranmer, J. Mater. Sci., 20(1985)2029.

8. K. F. Dufrane, J. Am. Ceram. Soc., 72 (1989) 691.

9. R. N. Katz, Treatise on Materials Science and Technology, 29(1989) 1.

10. P. K. Mehrotra, Int. Conf. on Wear of Materials, ASME, New York, 1987, pp. 301-312.

11. J. Breznak, E. Breval, and N. H. Macmillan, J. Mater. Sci. 20(1985)4657.

12. P. Sutor, Ceram. Eng. Sci. Proc. 5(1984)460.

13. P. Studt, Tribology Int., 22(1989)111.

14. P. Pool, Science, 246(1989) 444.

15. E. E. Klaus, J. L. Duda, and S. K. Naidu, National Institute of Standards and Technology Special Publication 744, U.S. Government Printing Office, Washington DC 20402 (1988).

16. J. Lauer and S. Dwyer, STLE Trans. 33(1990)529.

17. M. Kohzaki, S. Noda, H. Doi, and O. Kamigaito, Wear, 131(1989)341.

18. W. Wei, J. Lankford, and R. Kossowsky, Mat. Sci. Eng. 90(1987)307.

19. A. Erdemir, G. R. Fenske, R. A. Erck, and C. C. Cheng, Lubr. Eng., 46(1990) 23.

20. A. Erdemir, G. R. Fenske, F. A. Nichols, and R. A. Erck, STLE Trans., 33(1990)511.

21. R. A. Erck, A. Erdemir, and G. R. Fenske, Surf. Coat. Technol., 43/44(1990) 577.

22. A. Erdemir, D. E. Busch, R. A. Erck, G. R. Fenske, and R. Lee, Lubr. Eng., 47(1991)863.

23. A. Erdemir, A Review of the Lubrication of Ceramics with Thin Solid Films, in Friction and Wear of Ceramics, S. Jahanmir, Ed., Marcel Dekker, Inc., New York, 1993, pp 119-162. 24. A. Erdemir, R. A. Erck, G. R. Fenske, and F. A. Nichols, Proc. China Int. Symp. Youth Tribol., p.35, 1992.

25. Kyocera Co., Mechanical and Industrial Ceramics, Kyoto, Japan.

26. R. S. Gates, J. P. Yellets, D. E. Deckman, and S. M. Hsu, Selection and Use of Wear Tests for Ceramic, ASTM, STP 1010, Philadelphia, 1988, 1-23.

27.C. DellaCorte and H. E. Sliney, STLE Trans. 30(1987)30.

28. C. DellaCorte and H. E. Sliney, Lubr. Eng., 47(1991)298.

29. G. R. Fenske, A. Erdemir, C. C. Cheng, R. A. Erck, D. E. Busch, R. Lee, and F. A. Nichols, Lubr. Eng., 47(1991)104.

30. G. M. Hamilton and L. E. Goodman. J. Appl. Mech., 33(1966)371.

31. G. M. Hamilton, Proc. Instn. Mech. Engrs., 197C(1983)53.

32. A. Kerell and O. V. Bakun, Acta Metall., 34(1986)1315.

33. C. S. Yust and F. J. Carignan, ASLE Trans., 28(1984)245.

34. R. A. Erck and G. R. Fenske, Mat. Res. Soc. Symp., 47(1990)85.

35. R. A. Erck and G. R. Fenske, Lubr. Eng., 47(1991)640. 
36. J. T. Klomp, in S. D. Peteves (ed.), Designing Interfaces for Technological Applications: Ceramic-Ceramic, Ceramic-Metal Joining. Elsevier Science Publishers, London, England, 1989, p. 127.

37. A. Erdemir and C. C. Cheng, Ultramicroscopy, 29 (1989)266.

38. W. Mader, in R. W. Siegel, J. R. Weertman, and R. Sinclair (eds.), Materials Research Society Proceedings, Materials Research Society, Pittsburgh, PA, 1987, p. 403.

39. M. M. Karnowsky and W. B. Estill, Rev. Sci. Instrum., 35(1964)1324.

40. J. E. McDonald and J. G. Eberhart, AIME Trans., 233(1965)512.

41. Handbook of Chemistry and Physics, CRC Press., Boca Raton, FL, 1984. 


\section{FIGURE CAPTIONS:}

Fig. 1. A schematic illustration of ion-beam-assisted-deposition system.

Fig. 2. A schematic illustration of wear test machine.

Fig. 3. Variation of wear rates of alumina balls sliding against uncoated and silver-coated flats at different test temperatures (values in bottom table represent actual wear rates in $\left.10^{-7} \mathrm{~mm}^{3} / \mathrm{N} . \mathrm{m}\right)$

Fig. 4. 3-dimensional surface maps of wear tracks formed on (a) an uncoated $\mathrm{Al}_{2} \mathrm{O}_{3}$ flat and (b) an $\mathrm{Ag}-\mathrm{Nb}$-coated $\mathrm{Al}_{2} \mathrm{O}_{3}$ flat after tests at $600^{\circ} \mathrm{C}$.

Fig. 5. (a) General and (b) high-magnification SEM micrographs of a wear track formed on an $\mathrm{Ag}-\mathrm{Nb}$-coated $\mathrm{Al}_{2} \mathrm{O}_{3}$ flat during sliding against an $\mathrm{Al}_{2} \mathrm{O}_{3}$ ball at $200{ }^{\circ} \mathrm{C}$.

Fig. 6. SEM micrographs of silver films (a) without an $\mathrm{Nb}$ interlayer and (b) with an $\mathrm{Nb}$ interlayer after exposure to $600^{\circ} \mathrm{C}$.

Fig. 7. Friction coefficients of $\mathrm{Al}_{2} \mathrm{O}_{3}$ balls during sliding against uncoated and $\mathrm{Ag}$-coated flats at different temperatures. 


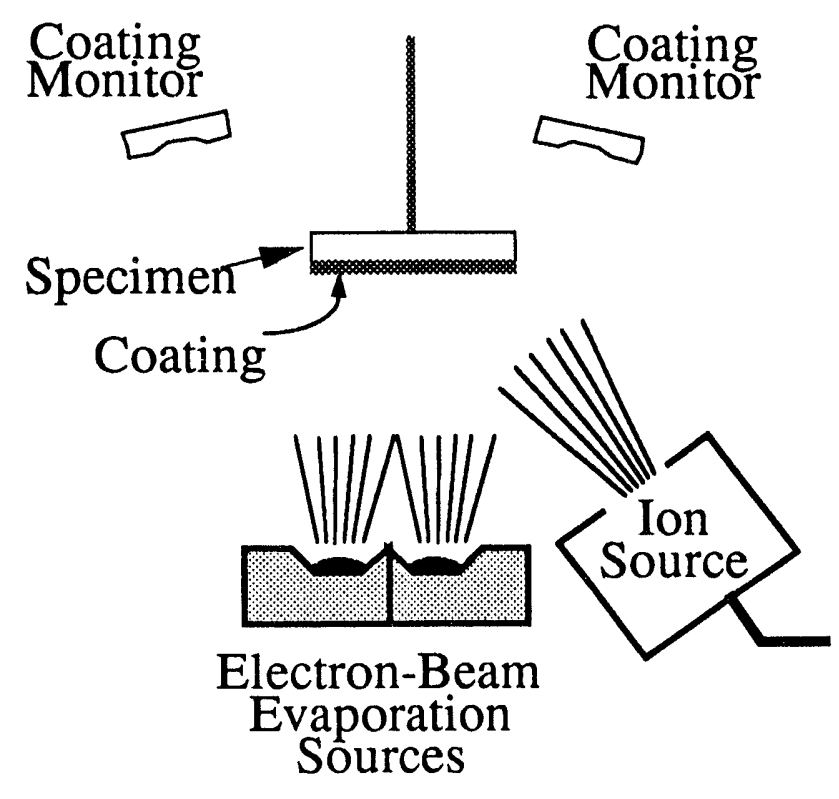

Fig. 1. A schematic illustration of ion-beam-assisted-deposition system.

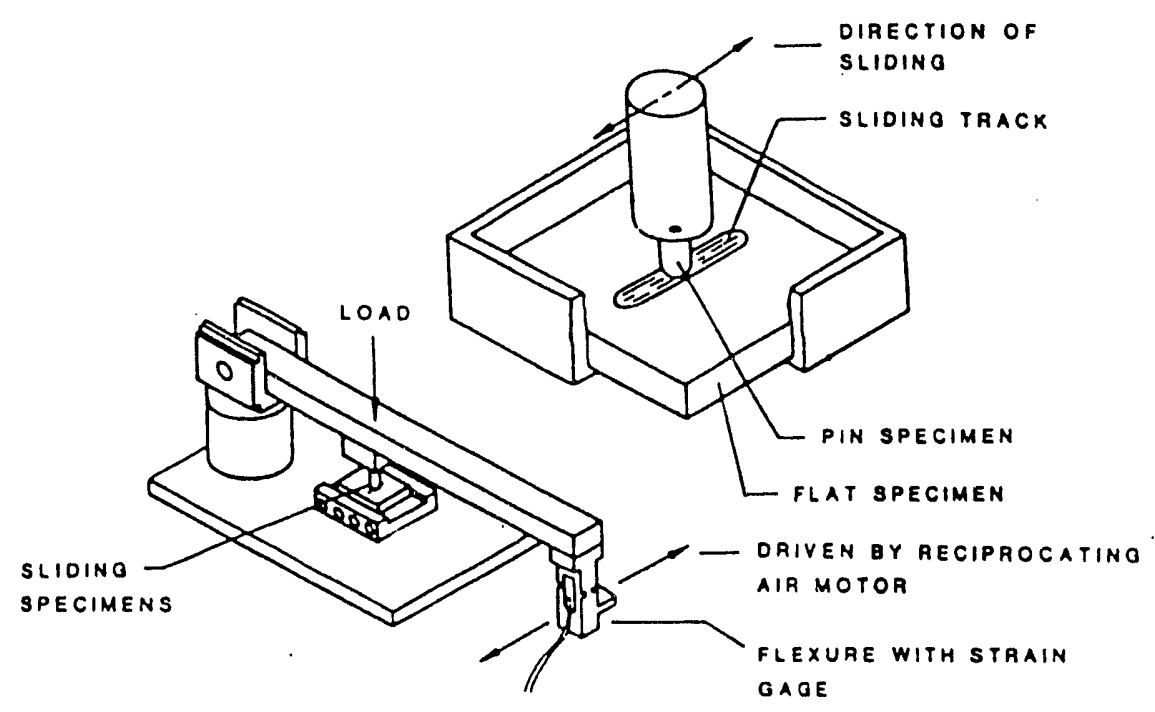

Fig. 2. A schematic illustration of wear test machine. 


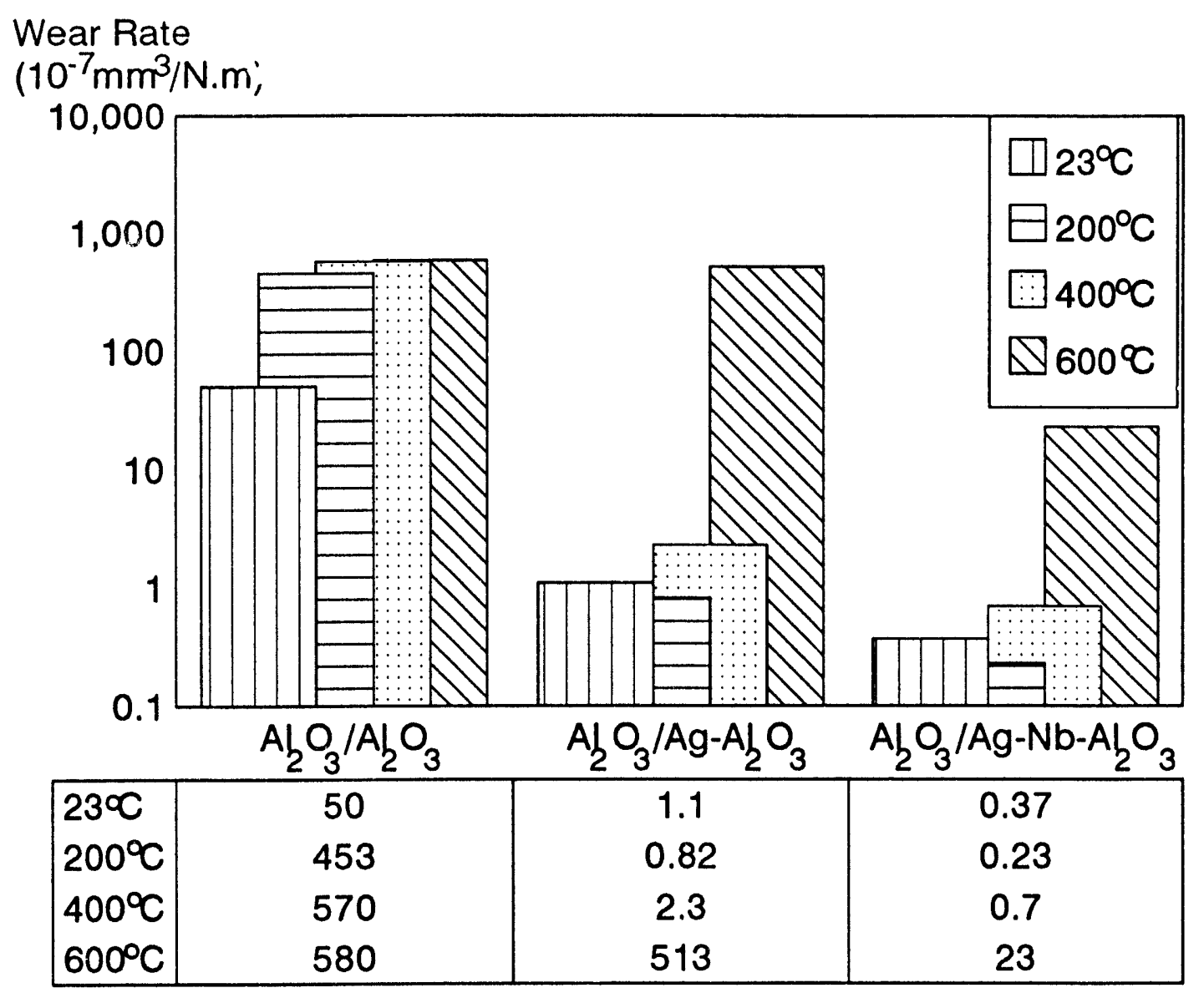

Fig. 3. Variation of wear rates of alumina balls sliding against uncoated and silver-coated flats at different test temperatures (values in bottom table represent actual wear rates in $10^{-7}$ $\mathrm{mm}^{3} / \mathrm{N} . \mathrm{m}$ ) 


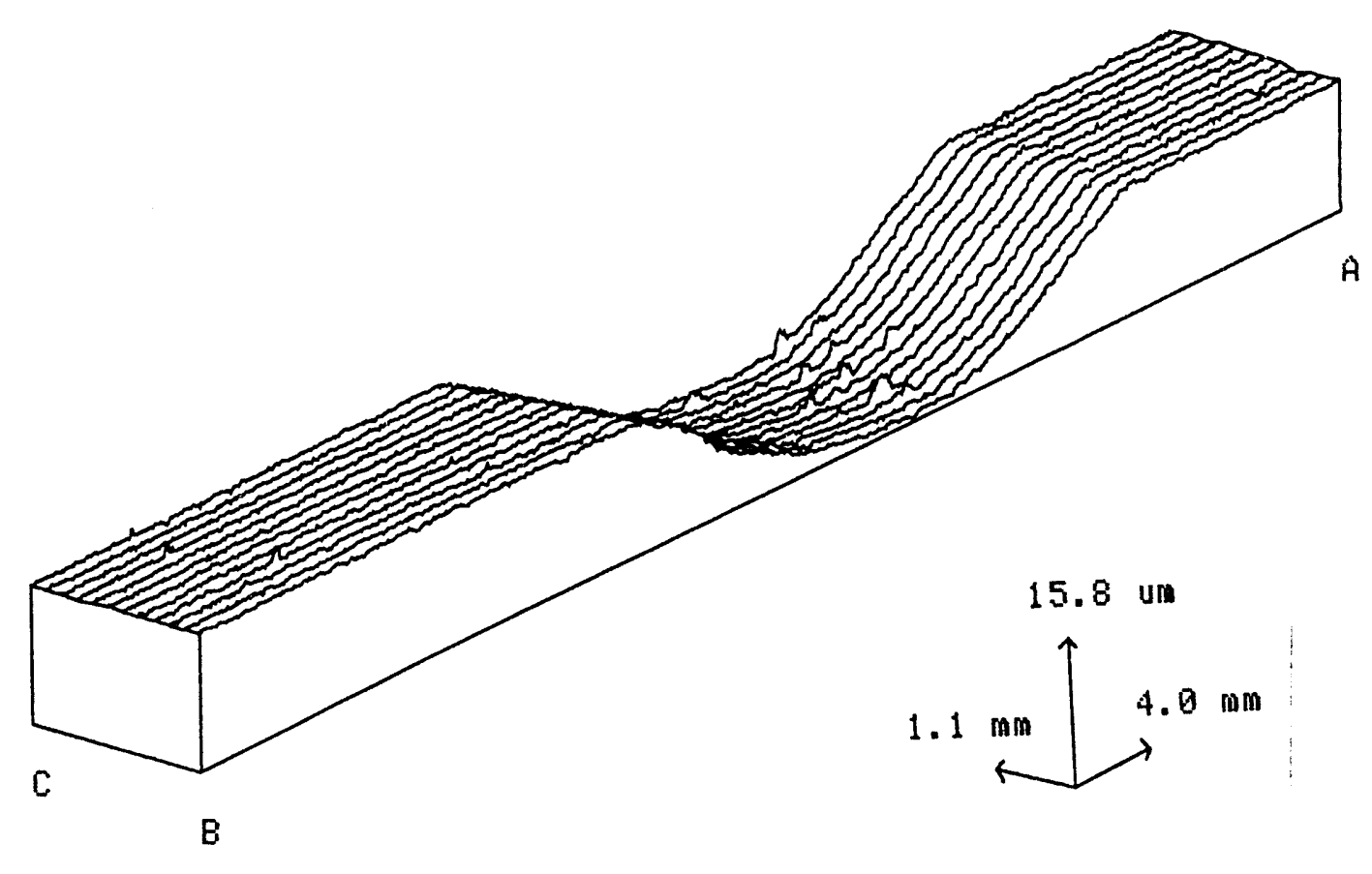

(a)

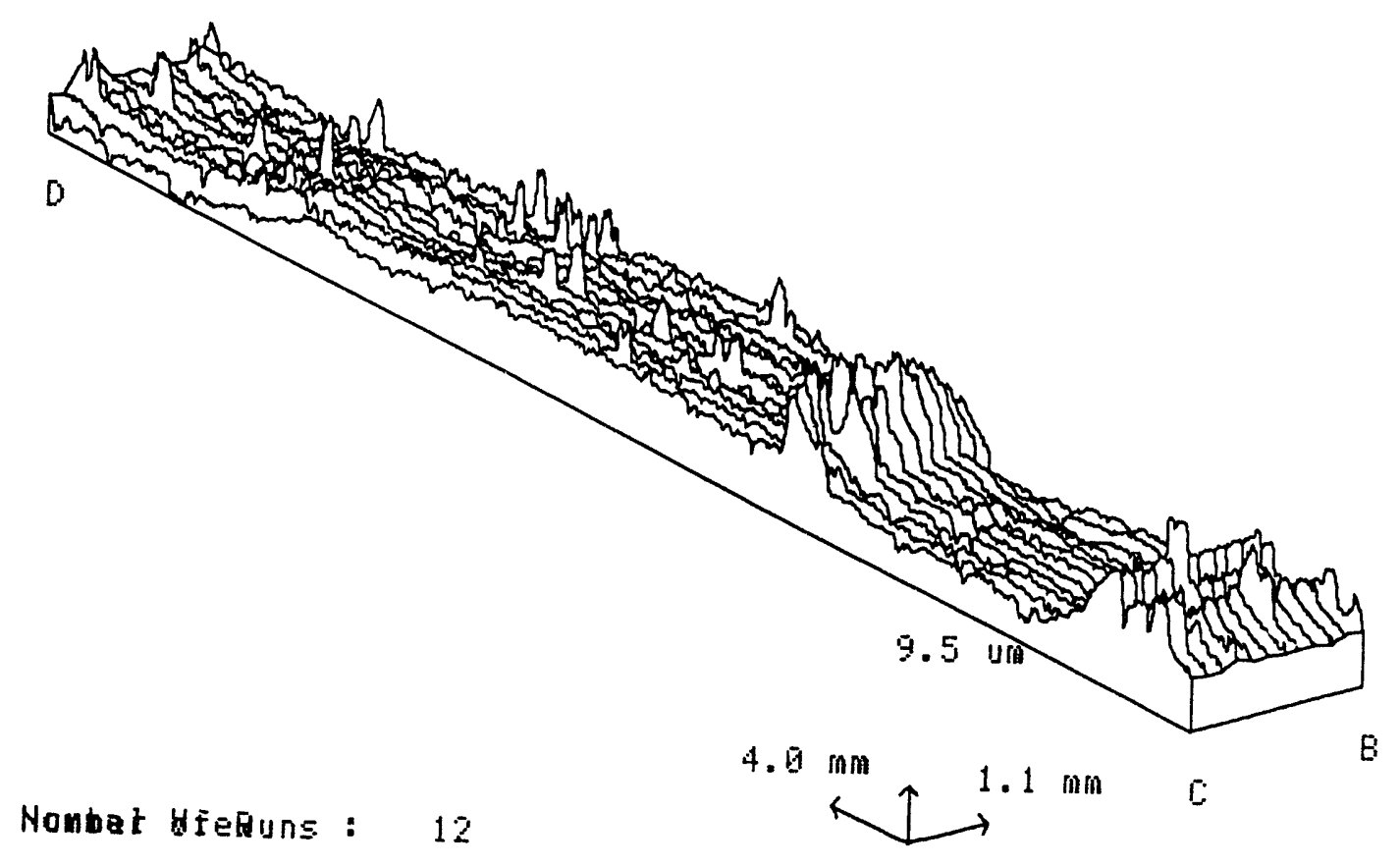

(b)

Fig. 4. 3-dimensional surface maps of wear tracks formed on (a) an uncoated $\mathrm{Al}_{2} \mathrm{O}_{3}$ flat and (b) an $\mathrm{Ag}$-Nb-coated $\mathrm{Al}_{2} \mathrm{O}_{3}$ flat after tests at $600^{\circ} \mathrm{C}$. 


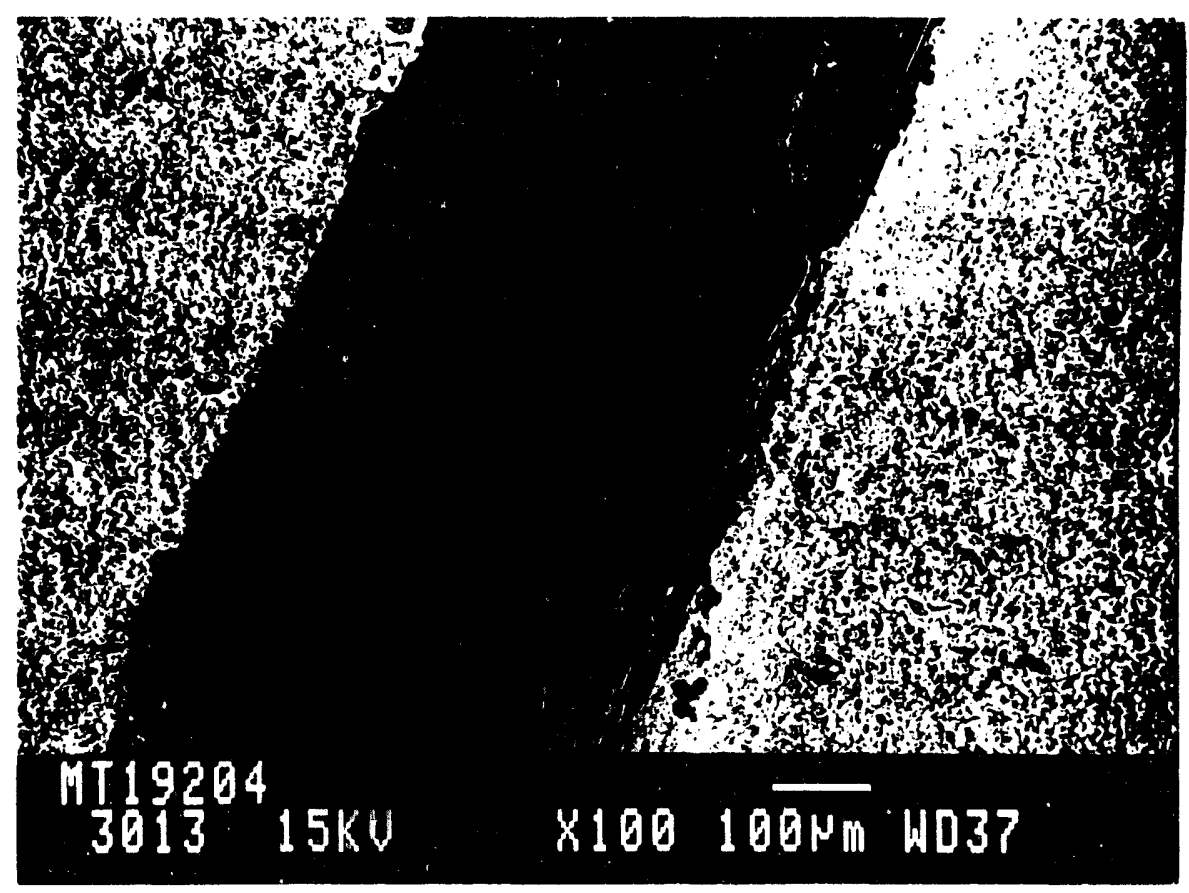

(a)

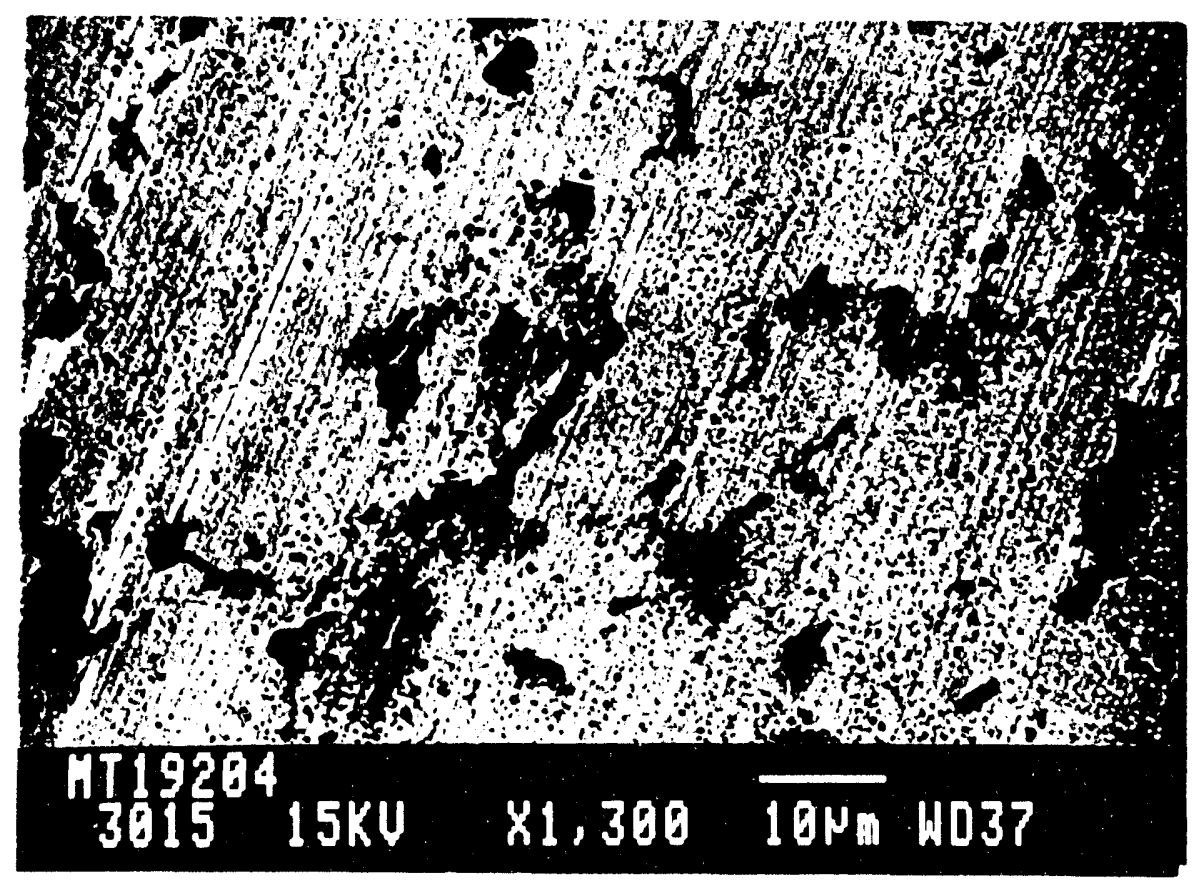

(b)

Fig. 5. (a) General and (b) high-magnification SEM micrographs of a wear track formed on an $\mathrm{Ag}-\mathrm{Nb}$-coated $\mathrm{Al}_{2} \mathrm{O}_{3}$ flat during sliding against an $\mathrm{Al}_{2} \mathrm{O}_{3}$ ball at $200{ }^{\circ} \mathrm{C}$. 


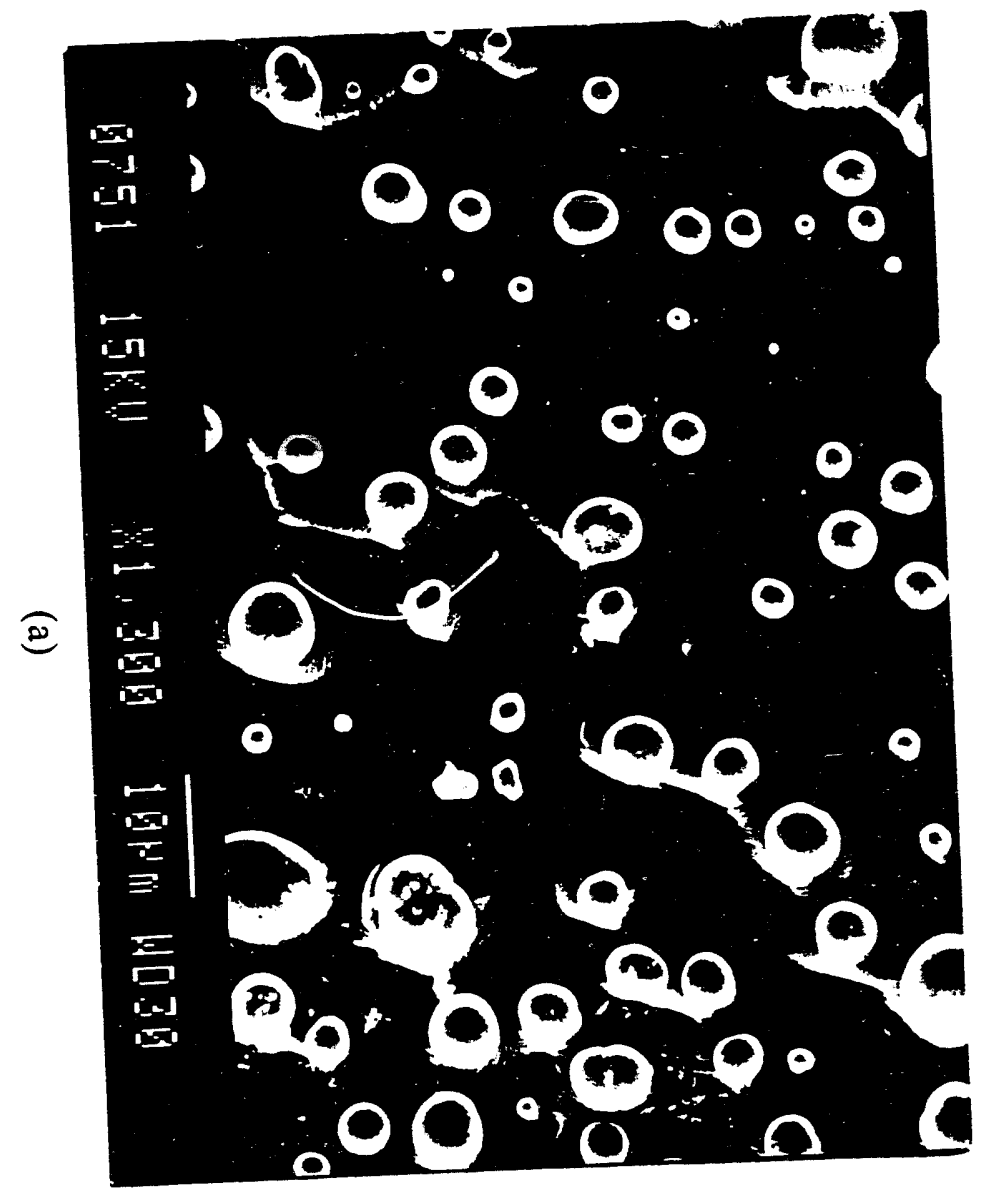




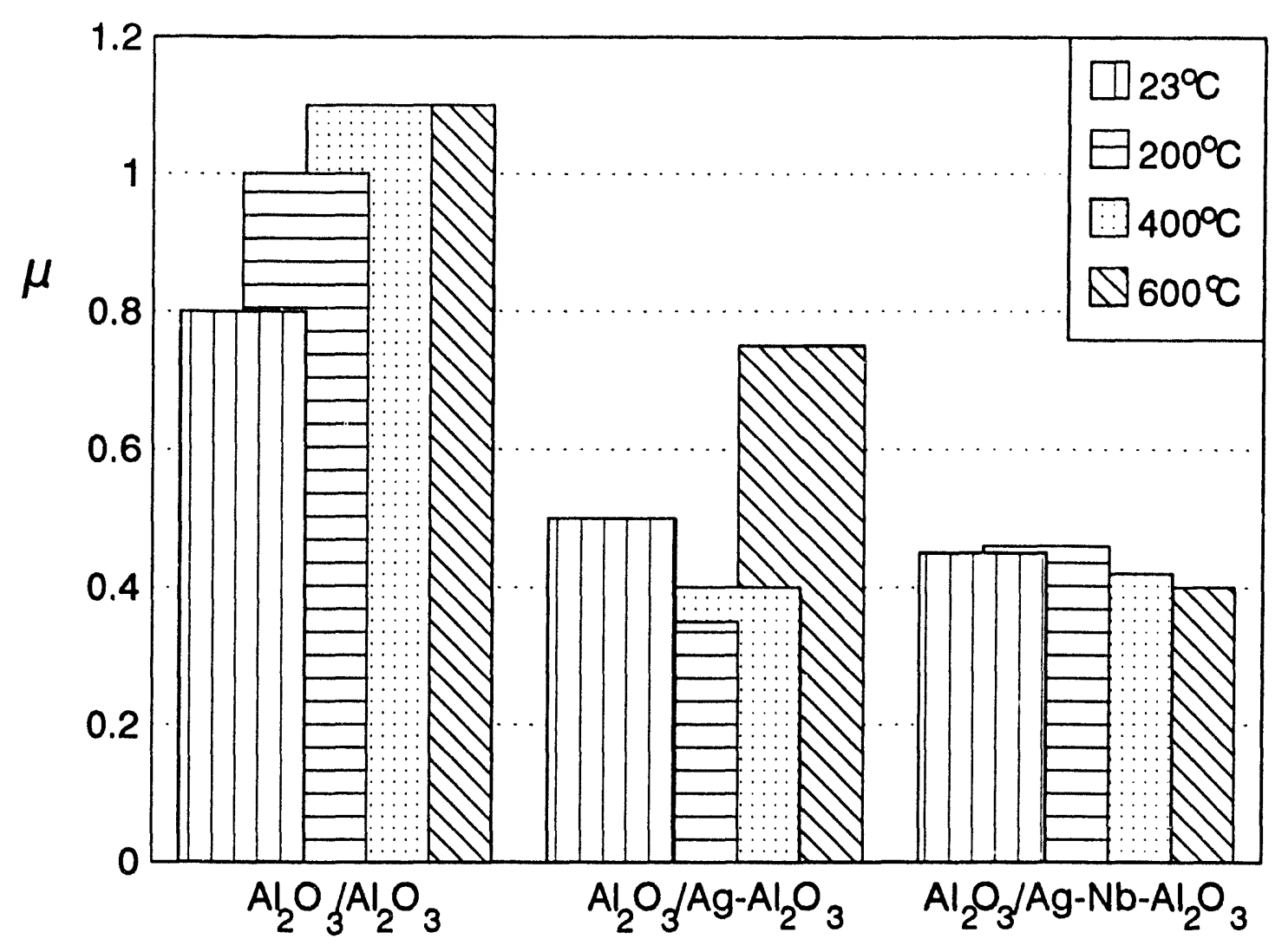

Fig. 7. Friction coefficients of $\mathrm{Al}_{2} \mathrm{O}_{3}$ balls during sliding against uncoated and $\mathrm{Ag}$-coated flats at different temperatures. 
